\title{
THE INFLUENCE OF SOCIETY TO THE STUDENTS SKILL IN ENGLISH TO THE SECOND YEAR STUDENT OF SMPN 5 TANDUN
}

\author{
Vera Vianti Mala \\ veravimail@yahoo.com
}

\begin{abstract}
The pupose of this research is carried out in order to find out how far the influence of society to the students skills in English to the second year students of SMPN 5 Tandun in 2018/2019 academic year is. The library research is applied based on the needs of the books as the sources of the theories and informations, and the field research is applied on the need of data from the field, in this case from SMPN 5 Tandun. As the instrument for collection the data, the writer uses test. After getting the data, the next step which is done by the writer is analizing it by using the statistical analysis. The students' skill English are also influenced by other factors, like the students' motivation, interest, aptitute, the method applied by the teachers in teaching, the school facilities, the family factor, etc. After finishing collecting and analyzing the data it has been known that there is a significant influence of society to the students' skill to the second year students of SMPN 5 Tandun. It means that the hypothesis of this research is accepted.
\end{abstract}

Keywords: Influence of Society, Students' Skills

\section{INTRODUCTION}

English as an international language has succeeded to attract most people all over the world to learn it. It can be seen from the interest of people to learn it and it is made as an obligatory subject in the school, both in the goverment and private school.

Like we seen in our country Indonesia, English is made as an obligatory subject, beginning from the primary school up to the University level. It is regarded important to be supplied for the students based on the considerations that by matering English students can improve their knowledge about natural sciences, sosial sciences, culture, etc. Because most of the books, magazines, and other written works are written in English. How ever, it is still found that even though the students have learned English for long time, their 
abilities are still low, both in speaking and writing. It is influenced by many factors. But in general, the factors that can influence the students' skill in learning can be divided into two parts, they are: internal factors and eksternal factors.

Based on the explanations the writer is interested to research about the factors that influence the students' abilities in learning English, in this case the writer focuses her research into one of the external factors, that is the factor of society, and makes the topic of research as follow: "The influence of society to the students' skill in English to the second year students of SMPN 5 Tandun"

Beside the above reasons, the writer has chosen the topic based on the following considerations:

1. The factor of society influences the student' skills in learning very much, especially in learning English.

2. The SMPN 5 Tandun is chosen based on the consideration that the writer teaches in this school, so that it is easy for the writer to get the needed data.

3. As far as the writer knows that the topic is still new for it has never researched by other researchers before.

The choice of the suitable problem is one of the most important task faced by researceher. It is said so, because teh problem is the spirit of research. A research can't be carried out without problem.

As Prof. Dr. S. Nasution MA states:
"Dalam penelitian masalah memegang peranan utama. Tanpa masalah tidak ada penelitian. Masalah adalah jiwa penelitian. Masalah mendorong untuk berpikir, menyelidiki agar menemukan makna sesuatu" (Nasution, 1989:22).

(The problem plays a main role in a research. There is no research without problem. The problem is the spirit of research. The problem motivates to think, to research in order to get something).

\section{THE}

THEORITICAL

\section{FRAMEWORKS}

The word "study" as a noun word means the process of getting or gaining knowledge of something.

As A.S Hornby states: "Study (noun) is process of gaining knowledge of a subject; An investigation of a subject" (Hornby, 1989:1277)

From the above explanations it can be stated that the word study in the topic of this research means the process of investigation which is done in order to get the knowledge, in this case the knowledge about influence of society to the students' skill in English to teh second year students of SMPN 5 Tandun in 2018/2019 academic year.

According to A.S Hornby, the word 'influence' as a noun word means: "power to produce an effect: action of natural forces" (Hornby, 1989:641)

And William Morris states:

"Influence means: (1). A power indirectly or intangibly affecting a person or a course of events. (2). Power to sway or effect based on prestige, wealth, ability or position. (3). A person 
or thing exercising such power" (Morris, 1984: 674)

The factor of society is one of the external factors taht exist in the outside of individuals who are learning. It is as one of the external factors which also influences the students' competences in learning. it is said so, because the students live in the society.

The factors of society include: (1). The students' activities in the society (2). Mass media (3). Associated friens, and (4). The way of life society.

\section{THE METHOD OF RESEARCH}

In carrying out a research, a reseacher can't be freed from method which is used in it. Based on the main purpose of this reseach, that is in order to find out about how far the influence of society to the students' skill in English to the second year students of SMPN 5 Tandun, so that in this research the writer uses the correlational method research.

For getting the data about the factor of society the writer distributes the questioners to the students. And then it is scored in order to get quantitative data. And in order to get data about the students' skill in English the writer uses document of school, in this case the list of scores collection of the students (Daftar Kumpulan Nilai Siswa) in 2018/2019 academic year.

After getting the data, both of the data about the influence of society an the data of the student' skill in English, the next step which is done by the writer is analyzing it by using the statistical analysis. It is done in order to find out how far the influence of society to the students' skill in English to the second year students of SMPN 5 Tandun.

Choosing the instrument for collection the data is assumed as an essential work in carrying out research. Therefore, it must be done well and seriously. The instrument should be appropriate to the usage and the variables of the research.

Referring to use of the method of the data, Dr. Suharsimi Arikunto states: "Sebagian besar penelitian umumnya menggunakan kuesioner sebagai metode yang dipilih untuk mengumpulkan data kuesioner atau angket memang mempunyai banyak kebaikan sebagai instrument pengumpul data" (Arikunto, 1989:180)

(The most the research use the questioners are the chosen method for collecting the data. Questioners really have many advantages as the instrument for collection data)

The number of questioner items in this research is 10 items, in which each item consist of three option, they are: $a, b$, and c.

\section{RESEARCH METHODOLOGY}

This research was conducted in a "True Experimental" post-test only control design. In this design, there were two groups taken randomly from certain populations.

For knowing about the influence of society the writer uses questionnaires as the instrument for collecting the data. The questioners consist of the list of the questions the relate to the society factors. The use of questioners is regarded appropriate to the variable of 
society factors. The questionnaire will describe about the insfluence of society.

After scoring the questionnaire that draws about the influence of society and after getting the data about the students' skill in English. The next step which is done by the writer is tabulating the data into the table of tabulation.

Table 3.1

The Tabulation Data

\begin{tabular}{|c|c|c|}
\hline \multirow{2}{*}{$\begin{array}{c}\text { No } \\
\text { Samples }\end{array}$} & \multicolumn{2}{|c|}{ Scores } \\
\hline & Questioners & English \\
\hline 1 & 80 & 75 \\
\hline 2 & 65 & 61 \\
\hline 3 & 70 & 65 \\
\hline 4 & 65 & 65 \\
\hline 5 & 70 & 65 \\
\hline 6 & 60 & 61 \\
\hline 7 & 65 & 60 \\
\hline 8 & 65 & 55 \\
\hline 9 & 70 & 65 \\
\hline 10 & 65 & 65 \\
\hline 11 & 75 & 60 \\
\hline 12 & 60 & 56 \\
\hline 13 & 75 & 70 \\
\hline 14 & 65 & 68 \\
\hline 15 & 65 & 65 \\
\hline 16 & 75 & 70 \\
\hline 17 & 65 & 68 \\
\hline 18 & 80 & 70 \\
\hline 19 & 65 & 65 \\
\hline 20 & 75 & 71 \\
\hline 21 & 65 & 65 \\
\hline 22 & 75 & 70 \\
\hline 23 & 80 & 70 \\
\hline 24 & 70 & 70 \\
\hline 25 & 70 & 70 \\
\hline 26 & 65 & 65 \\
\hline 27 & 70 & 60 \\
\hline 28 & 65 & 68 \\
\hline 29 & 70 & 68 \\
\hline 30 & 65 & 70 \\
\hline
\end{tabular}




\begin{tabular}{|l|l|l|}
\hline 31 & 65 & 68 \\
\hline 32 & 70 & 68 \\
\hline
\end{tabular}

After getting data, both of the data about influence of society and the students' skill in English the it is analyzed by using the statistical. The statistical analysis is treated in order to find out about how far the influence of society to the students' skill in Englis to the second year students of SMPN 5 Tandun. The testing of hypothesis ca only done if the reseach has finished collecting and analyzing the data.

After finishing collecting and analyzing the data it has been known that there is a significant influence of society to the students' skill to the second year students of SMPN 5 Tandun. It means that the hypothesis of this research is accepted.

\section{FINDING AND DISCUSSION}

As it has been stated before that after getting the data from the field, they are: the quantitative data about the society and list of score collection of the students in English, the it is analysis is applied in order to find out how far the influence of society to the students' skills in English to the second year students of SMPN 5 Tandun Rokan Hulu in 2018/2019 academic year is.

Table 4.1. The Analysis of Data

\begin{tabular}{|c|c|c|c|c|c|}
\hline No & $\mathbf{X}$ & $\mathbf{Y}$ & $\mathbf{X}^{\mathbf{2}}$ & $\mathbf{Y}^{\mathbf{2}}$ & $\mathbf{X Y}$ \\
\hline 1 & 80 & 75 & 6400 & 5625 & 6000 \\
\hline 2 & 65 & 61 & 4225 & 3721 & 3965 \\
\hline 3 & 70 & 65 & 4900 & 4225 & 4550 \\
\hline 4 & 65 & 65 & 4225 & 4225 & 5225 \\
\hline 5 & 70 & 65 & 4900 & 4225 & 4550 \\
\hline 6 & 60 & 61 & 3600 & 3721 & 3660 \\
\hline 7 & 65 & 60 & 4225 & 3600 & 3900 \\
\hline 8 & 65 & 55 & 4225 & 3600 & 3575 \\
\hline 9 & 70 & 65 & 4900 & 4225 & 4550 \\
\hline 10 & 65 & 65 & 4225 & 4225 & 4225 \\
\hline 11 & 75 & 60 & 5625 & 3600 & 4500 \\
\hline 12 & 60 & 56 & 3600 & 3136 & 3360 \\
\hline 13 & 75 & 70 & 5625 & 4900 & 5250 \\
\hline 14 & 65 & 68 & 4225 & 4624 & 4420 \\
\hline 15 & 65 & 65 & 4225 & 4225 & 4225 \\
\hline 16 & 75 & 70 & 5625 & 4900 & 5250 \\
\hline 17 & 65 & 68 & 4226 & 4624 & 4420 \\
\hline 18 & 80 & 70 & 6400 & 4900 & 5600 \\
\hline 19 & 65 & 65 & 4225 & 4225 & 4225 \\
\hline
\end{tabular}




\begin{tabular}{|c|c|c|c|c|c|}
\hline 20 & 75 & 71 & 5625 & 5041 & 5325 \\
\hline 21 & 65 & 65 & 4225 & 4225 & 4225 \\
\hline 22 & 75 & 70 & 5625 & 4900 & 5250 \\
\hline 23 & 80 & 70 & 6400 & 4900 & 5600 \\
\hline 24 & 70 & 70 & 4900 & 4900 & 4900 \\
\hline 25 & 70 & 68 & 4900 & 4624 & 4760 \\
\hline 26 & 65 & 65 & 4225 & 4225 & 4225 \\
\hline 27 & 70 & 60 & 4900 & 3600 & 4200 \\
\hline 28 & 65 & 68 & 4226 & 4624 & 4420 \\
\hline 29 & 70 & 68 & 4900 & 4624 & 4760 \\
\hline 30 & 65 & 70 & 4225 & 4900 & 4550 \\
\hline 31 & 65 & 68 & 4226 & 4624 & 4420 \\
\hline 32 & 70 & 68 & 4900 & 4624 & 4760 \\
\hline TOTAL & $\mathbf{2 2 0 5}$ & $\mathbf{2 1 1 0}$ & $\mathbf{1 5 2 8 7 8}$ & $\mathbf{1 4 0 3 3 7}$ & $\mathbf{1 4 6 8 4 5}$ \\
\hline
\end{tabular}

From the above table of statistical computation, it can be seen that the values of:

$\sum X=2205$

$\sum \mathrm{Y}=4715$

$\sum X^{2}=152878$

$\sum Y^{2}=140337$

$\sum Y=146845$

$\mathrm{N}=32$

From the above value correlation, and after colsulting it to table of interpretation it can seen that the value of correlation can be interpreted into the sufficient correlation category. it means that there is a significan influence of society to the students' skill in English to the second year students of SMP Negeri 5 Tandun Rokan Hulu in 2018/2019 academic year.

\section{CONCLUSIONS SUGGESTIONS}

AND

\section{Conclusions:}

1. There is a significant influence of society to the students' skill in English to the second year student of SMPN 5 Tandun in 2018/2019 academic year.

2. The students' skill English are also influenced by other factors, like the students' motivation, interest, aptitute, the method applied by the teachers in teaching, the school facilities, the family factor, etc.

3. The influence of society can be categorized into the good category.

4. The skill of the second year students of SMPN 5 Tandun in English can be categorized into the capable category.

5. The hypothesis of this research is accepted. 
The Suggestion:

1. In order to improve the students' skill in English, it is suggested to the people who involved in the educational field to pay their special attention to the factor that influence the students' skill in learning, they are: internal factors and external factors.

2. It is suggested to the students to choose the good friends, because it can influence their learning to the positive direction.

3. It is suggested to the students to follow the positive activities in the society, such as: following the discussion group, the courses, the religions activities, etc.

4. It is suggested to the students to learn English well, because English is used as International language and it is used as a media of transferring the knowledge.

\section{BIBLIOGRAPHY}

1. Arikunto, Suharsimi. 2006.

Prosedur Penelitian Suatu

Pendidikan Praktik. Jakarta:

Rineka Cipta.

2. Brown,H.Douglas.2004.

Language Assessment Principles And Classroom Practices. Longman : San Fransisco State University.

3. Jollife,Wendy.2007.

Cooperative Learning In The

Classroom Putting It Into

Practice.
4. Nunan, David.2005. Practical english language teaching young learner

5. Nasution S, Metode Research, Jemmars, Bandung, 2001.

6. Nazir,Moh.2003. Metode Penelitian.Jakarta : Galia Indonesia

7. Sudjana, Nana. 2007. Penelitian dan Penilaian Pendidikan. Bandung: Sinar Baru Algensindo. 
Balnk Page 